\title{
Trans-abdominal and Trans-gastric percutaneous drainage of peripancreatic infected collections: a retrospective analysis.
}

Carlos Rey ( $\sim$ carlosrey991@gmail.com )

Méderi: Hospital Universitario Mayor https://orcid.org/0000-0001-6888-5595

\section{Danny Conde}

Méderi: Hospital Universitario Mayor

\section{Felipe Girón}

Rosario University: Universidad Del Rosario

\section{Daniela Ayala}

Rosario University: Universidad Del Rosario

\section{Juliana Gonzalez}

Rosario University: Universidad Del Rosario

\section{Marco Quintero}

Méderi: Hospital Universitario Mayor

\section{Research Article}

Keywords: Acute pancreatitis, radiology interventional, drainage, peripancreatic necrosis

Posted Date: February 17th, 2022

DOI: https://doi.org/10.21203/rs.3.rs-1297063/v1

License: (1) This work is licensed under a Creative Commons Attribution 4.0 International License. Read Full License 


\section{Abstract}

\section{Purpose}

Acute pancreatitis is one of the most common gastrointestinal diseases. Approximately $20 \%$ of the patients develop peripancreatic collections. Step-up management it's now the best approach with less rate of morbidity and mortality compared with open or minimally invasive surgery. Percutaneous management could reach a success rate between $50-76 \%$. Our study shows the outcomes of trans-gastric versus transabdominal percutaneous drainage in cases of peripancreatic collections.

\section{Methods}

A retrospective review of a prospectively collected database was conducted. All the patients older than 18 years old that underwent percutaneous drainage between January 2010 - December 2021 were included. Analysis and description of outcomes such as mortality, complications, and avoidance of surgical procedures was performed.

\section{Results}

18 patients underwent percutaneous drainage. $66.67 \%$ of patients were male. Mean age was $52.55 \pm$ 22.06 years. Mean weight was $74.43 \pm 15.25 \mathrm{~kg}$. Mean size of peripancreatic collections $118.4 \pm$ $49.12 \mathrm{~mm}$. Wall-off necrosis was present in $33.33 \%$. Trans-gastric approach was performed in $50 \%$ of the cases, the rest was trans-abdominal. No mortality was evidenced after 30 days of follow up. After transgastric percutaneous drainage, all patients avoided surgical open or laparoscopic procedure

\section{Conclusion}

Standardized step-up approach shows increased rates of success in percutaneous drainage of peripancreatic collections. Based on our results, in the absence of interventionist endoscopy, percutaneous drainage (trans gastric or trans-abdominal) it's a feasible and secure procedure. Further studies are needed.

\section{Background}

Acute pancreatitis (AP) is defined as an inflammatory process of the pancreatic gland associated to local and systemic inflammatory response, being one of the most common gastrointestinal diseases with an incidence of 34 per 10.0000 habitants per year in high income countries [1]. In our country, there is no specific epidemiological data, therefore it has not been possible to establish the real incidence of the disease and its management outcomes [2].

Around $80 \%$ of the acute pancreatitis are attributed to gallstones, followed by alcohol in $9 \%$ of the cases and $5 \%$ secondary to traumatic events; the remaining percentage is due to other multiple etiologies including pharmacological induced among others [3]. Its clinical presentation encompasses a wide 
spectrum of signs and symptoms being abdominal pain the main symptom at the disease onset usually a band-like pain associated with emetic episodes in $80 \%$ of patients [4]. Acute pancreatitis severity is highly variable, ranging from self-limited episodes to multiorgan failure [4].

Risk factors such as diabetes mellitus, in-hospital infections and advanced age established as $>70$ years have been identified as poor prognosis factors, nevertheless, main mortality predictor is persistent organ failure after 48 hours [5]. Almost $20 \%$ of the patients with acute pancreatitis develop a complicated clinical course that can progress and lead to fatal outcomes [6]. The Atlanta classification divides AP into mild, moderately severe, and severe disease, defined by the presence of organ failure and local and systemic complications [7]. Despite the etiological differences, mortality rates are about $4-5 \%$ in mild acute pancreatitis and 30 to $50 \%$ in severe pancreatitis [8].

Acute pancreatitis diagnosis is confirmed by the presence of clinical, chemical, and imaging findings. The imaging evaluation depends on the medical criteria and the clinical evolution of the patient. These are usually suggested when there is diagnostic doubt, deterioration, multiple organ failure and suspected complications [9][10][11]. The abdominal ultrasound, computerized axial tomography and the magnetic resonance are essential for determining the etiology, however, ultrasound lacks efficacy due to the frequent interposition of gas; while the TC is the gold standard for diagnosis, classification, and identification of complications [9]. Imaging findings are interpreted in the context of severity using the tomographic severity index (CTSI).

Treatment of acute pancreatitis has evolved over the years, currently it is based on has 4 pillars: early intravenous hydration, adequate nutrition, analgesia, and additional necessary interventions. Although consensus has been reached on the nomenclature, there are still no definitive agreements on treatment options [8][9][12]. Once a torpid clinical progression of patients, complications must be ruled out differentiating them into systemic (transitory and persistent organ failure) and local complications. The Atlanta consensus (1992), generated a universally nomenclature that classified local complications into 5 types, based on imaging findings: Peripancreatic acute liquid collections, acute necrotic collection, pancreatic pseudocyst, walled-off necrosis, and infected necrosis.

Adequate drainage of infected necrotic collections is the fundamental pillar in the treatment of these patients, in conjunction with opportune antibiotic therapy and multidisciplinary medical management. Percutaneous drainage is routinely performed guided by computed tomography and has represented an advance in the management of peripancreatic collections. Its use is recommended in the literature mainly as a bridging therapy in those patients with infected necrosis in whom it is necessary to stabilize the septic process before considering surgical management, although recent studies have shown efficacy of approximately $40 \%$ as the only treatment. [13][14][15]. The percutaneous management of the collections control the origin of the infection by removing the infected fluid, reducing surgical stress and the complications associated with conventional interventions [15], The success rate of percutaneous drains varies between 14 and $86 \%$ with low mortality and morbidity, and accompanied by drains rigorous care, correct cleaning and frequent irrigation could improve even more the result of the technique [14][15][16] 
[17]. The approach to pancreatic collections is initially considered as a minimally invasive procedure since lower rates of complications have been demonstrated. Percutaneous procedures can be performed in the earliest stages of the evolution, with relative safety and effectiveness, reducing local complications and the patient's systemic inflammatory response [13][14][16]. The aim of this study, it's to describe the experience and outcomes in management of infected pancreatic necrosis by percutaneous drainage (trans-abdominal and trans-gastric approach)

\section{Methods}

\section{Study population}

With the Institutional (Hospital Universitario Mayor Méderi) Review Board's approval and following Health Insurance Portability and Accountability Act (HIPAA) guidelines, a retrospective review of a prospectively collected database was conducted. All patients over 18 years of age that underwent percutaneous drainage of peripancreatic infected collections due to acute biliary pancreatitis between January 2014 and May 2021 were included. Patients with no post-drainage evolution and missing data were excluded. Ethical compliance with the Helsinki Declaration, current legislation on research Res. 008430-1993 and Res. 2378-2008 (Colombia) and the International Committee of Medical Journal Editors (ICMJE) were ensured under our Ethics and Research Institutional Committee (IRB) approval.

\section{Data Management}

Descriptive statistics were reported in terms of variable nature. Qualitative analysis was performed in terms of frequencies and percentages, while quantitative analysis was done in terms of mean and standard deviations of normally distributed data and medians and interquartile ranges (IQRs) for nonnormally distributed data.

\section{Percutaneous Management}

All patients that present acute local infected complications due to acute biliary pancreatitis such as peripancreatic collections, or necrotic infected collections were assessed by a single intervencionist radiologist. Decision of percutaneous drainage was defined by clinical deterioration, increased inflammatory signs, and elevation of laboratory markers such as white blood cells, reactive $\mathrm{C}$ protein, and procalcitonin following step-up management for infected pancreatic necrosis. Drainage was performed with a pig-tail drainage directed to the collection in all cases. Requirement of new drainage was defined by non-improvement in clinical condition, and tomographic evidence of collection persistence. Transabdominal or trans-gastric management were performed, depending on the localization and technical availability to perform the procedure. All procedures were performed with a sonographic guide initially, and in technically difficult cases, with a tomographic guide. (See figure 1) . 


\section{Follow Up}

Patients were assessed until 1 hour after the procedure, to avoid immediate post-procedure complications. All patients were evaluated by a general surgeon after the procedure, and with close evaluation of vital signs, arterial gasometry, and clinical assessment. In cases of Intensive care unit stay, a closer surveillance was performed. Post - procedure tomography only was performed if patients have a worse clinical course. All patients were evaluated after resolution of the complication in external valoration by a general surgeon.

\section{Results}

\section{Demographic characteristics}

In our institution, between 2014-2021, 1020 episodes of acute biliary pancreatitis, and 35 patients present infected peripancreatic collections with or without necrosis. 18 patients underwent percutaneous drainage and were included in the study, the remaining patients $(n=17)$ technical difficulties don't allow the percutaneous intervention and require surgical management (open and laparoscopic debridation). $66.67 \%$ of patients were male. Mean age was $52.55 \pm 22.06$ years. Mean weight was $74.43 \pm 15.25 \mathrm{~kg}$. History of arterial hypertension was presented in $22.22 \%$, type 2 diabetes mellitus in $5.5 \%$. (See table 1). In all cases aetiology of pancreatitis was biliary.

Table 1

Demographic Characteristics

\begin{tabular}{|lll|}
\hline Variable & Result \\
\hline Gender \% (n) & & \\
\hline Male & $66.6(12)$ & \\
\hline Female & $33.3(6)$ & \\
\hline & Mean & SD \\
\hline Age & 52.5 & 22.06 \\
\hline Weight & 74.4 & 15.25 \\
\hline Comorbidities \%(n) & & \\
\hline No-Comorbidities & $66.6(12)$ & \\
\hline Arterial Hypertension & $22.2(4)$ & \\
\hline Type 2 Diabetes & $5.5(1)$ \\
\hline Chronic Renal disease & $5.5(1)$ \\
\hline
\end{tabular}




\section{Peripancreatic Collection Characteristics}

Computed tomography severity index (CTSI) score was assessed, and classified as: mild (0-3), moderate (4-6), and severe (7-10). Majority of the patients $83.33 \%$ presented with a severe CTSI score. Fluid characteristics based on tomography images were defined as: heterogeneous or homogeneous; in our population, in most of the cases, collection was heterogeneous. (83.33\%). As well, pancreatic necrosis was evaluated and classified > or equal than $30 \%$; in the patients included in the study, most of the patients present with more than $30 \%$ of pancreatic necrosis $(61.11 \%)$. Size of the peripancreatic collection was calculated based on tomographic findings with a mean size of $118.4 \pm 49.12 \mathrm{~mm}$. Wall-off necrosis was present in $33.33 \%$. In all cases, fluid collections were cultivated; findings are summarized in Table 2. 
Table 2

Peripancreatic collection characteristics

\begin{tabular}{|ll|}
\hline Variable & Result \\
\hline CTSI \% (n) & \\
\hline Mild & $16.6(3)$ \\
\hline Moderate & $0(0)$ \\
\hline Severe & $83.3(15)$ \\
\hline Fluid \% (n) & \\
\hline Heterogeneous & $83.3(15)$ \\
\hline Homogeneous & $16.6(3)$ \\
\hline Pancreatic necrosis \% (n) & \\
\hline$<30 \%$ & $38.8(7)$ \\
\hline$>30 \%$ & $61.1(11)$ \\
\hline Type of collection \% (n) & \\
\hline Peripancreatic Collection & $66.6(12)$ \\
\hline Wall-off Necrosis & $33.3(6)$ \\
\hline Culture \% (n) & \\
\hline E. Coli & $50(9)$ \\
\hline K. Pneumoniae & $33.3(6)$ \\
\hline Lactococcus & $5.5(1)$ \\
\hline Candida Albicans & $11.1(2)$ \\
\hline Size of the collection & 118.27 mm \\
\hline
\end{tabular}

\section{Outcomes}

Multi-organic dysfunction was present in $94.4 \%$ of the patients prior to percutaneous drainage. After the procedure, only $5.5 \%$ of the cases did not modify clinical conditions of organic dysfunction. In $94.4 \%$ of the population, percutaneous drainage was considered successful, by avoiding pancreatic surgery (debridation, necrosectomy, laparoscopic debridation). Number of required drainages were evaluated as well, the majority of the patients $(87.50 \%$ ) only needed one procedure, $6.25 \%$ required two, and $6.25 \%$ required three percutaneous drainages. In all cases, only one pigtail catheter was placed in the collection. 
Tomographic guide was the most frequently used, in $83.33 \%$ of the cases. Trans-gastric approach was performed in $50 \%$ of the cases, the rest was trans-abdominal. No mortality was evidenced after 30 days of follow up. Management of drains were teached to the patients, and all follow up was performed by a pancreatic surgeon out-hospital.

\section{Trans - abdominal versus trans-gastric drainage.}

After trans-gastric percutaneous drainage, all patients avoided surgical open or laparoscopic procedure; compared with trans-abdominal approach in that one patient's procedure was considered unsuccessful, and patient required laparoscopic drainage of infected pancreatic necrosis. There was a slight difference in the approach in terms of improvement of organ dysfunction. (Trans-abdominal 1 patient improves organ dysfunction compared with 0 in trans-gastric approach). Sonographic approaches were preferred in cases of trans-abdominal drainage, and tomographic approaches were the most frequent guide in cases of trans-gastric procedure. (See Table 3).

Table 3

Trans-abdominal versus Trans-gastric percutaneous drainage

\begin{tabular}{|lll|}
\hline Variable & TAPD & TGPD \\
\hline Successful drainage \% (n) & $88.8(8)$ & $100(9)$ \\
\hline Organ dysfunction improvement \% (n) & $12.5(1)$ & $0(0)$ \\
\hline Required surgical procedure \% (n) & $12.5(1)$ & $0(0)$ \\
\hline Tomographic approach \% (n) & $77.8(7)$ & $88.8(8)$ \\
\hline Sonographic approach \% (n) & $25 \%(2)$ & $12.5(1)$ \\
\hline Required drainages Mean $(\mathbf{s d})$ & $1.44(0.72)$ & $1(0)$ \\
\hline
\end{tabular}

\section{Discusion}

Evolution of AP into necrotizing pancreatitis has an increased rate of mortality, reaching $35 \%$ in some cases of series (19). Effectiveness in the treatment of peripancreatic collections associated with necrotic tissue are well described in the literature; in previous years, open necrosectomy was considered the gold standard in the management of this complication (19), however, minimally invasive approach was explored to avoid surgery, and prevent surgical morbidity (19). PANTER trial $(19,20)$, demonstrate the numerous benefits of an "step - up" approach over open surgery; with lesser proportion of complications, and reduced time of recovery, and less rate of mortality in cases of percutaneous drainage $(19,20)$; also, PENGUIN trial, shows benefit of endoscopic approach over surgery in the same postoperative outcomes (21). Surgical approach shows an increased rate of mortality, reaching almost $42 \%$ in some series reported (19). For that reason, the step-up approach in general surgery departments should be standardized to reduce mortality rates and prevent chronic morbidity. 
Success rate of percutaneous drainage is in a range of $0-78 \%$ in some series of cases (22), and it is referred to most of the times in terms of avoiding surgical procedures or mortality rates (22). Freeny et al (23), was the first author to describe the effectiveness of percutaneous drainage and shows a success rate of $47 \%$ in well selected cases and be able to decrease the multi-organ failure (23). However, success rate is related to a multidisciplinary approach, gathering interventionist radiologists, gastroenterologists, general surgeons, pancreatic surgeons, and intensive care units' members. Sharma et al (22), report a high rate of success in CT guided percutaneous drainage, with $85,7 \%$, avoiding surgical approach in $75 \%$ of the cases. As well, Wronski et al (24), shows a $33 \%$ of success rate in ultrasound guided percutaneous drainage, and could be used as a definitive approach to avoid surgery and reach complete resolution of the complication (24). These results are comparable with ours, with a success rate of $94.4 \%$ of the cases, with no complications after 30 days of follow up.

Tomographic guide it's the most frequent one used; only 4 authors described their experience using ultrasound guide in peripancreatic drainage (24); in our population no differences between the radiologic approach, however, it's important to declare that in cases of increased technical difficulty CT guide was preferred over ultrasound, depending on the radiologist experience.

Is well known that infected peripancreatic collections are related with bacterial infection (22), in the majority of the cases, E.Coli and and E. Faecioum were the most frequent bacteria isolated (22). In our population, no gram-positive bacteria were obtained, and E. Coli remains to be the most persistent bacteria isolated; however, fungi is a microbiological concern that needs to be in our minds in critically ill patients as we can see in our population with $11.1 \%$ of the cases.

The use of more than one catheter, it's related to increased success rates in patients with large collections with infected necrosis, lavage of the cavity could be related with better outcomes because, the use of saline solution could reduce the rate of debris and necrotic tissue that is susceptible of infection (22-24).

Some literature reports the trans gastric percutaneous approach in the drainage of pancreatic pseudocyst and collections (25-27), however, with the adveniment of endoscopic procedures, these interventions are abandoned, and replaced with endoscopic ultrasound guided drainage or cystogastrostomy. Nevertheless, in some low-income countries, interventionist endoscopy is not available, and expertise in interventionist radiologists have an increased importance in the management of these conditions.

In our population, trans-gastric approach shows comparable results with trans-abdominal approach, with increased rate of success, and achieves a $100 \%$ rate of avoiding surgical procedures, with no complications after 30 days of follow up. To the best of our knowledge, our study is the first one to describe the transgastric approach in the management of percutaneous infected necrosis, with an increased rate of success, comparable with endoscopic approach.

Limitations of our study, includes the retrospective nature, and the limited number of cases (related with the proportion of patients that develop infected pancreatic necrosis), as well, in our center the non- 
availability of ultrasound-endoscopic guide to perform endoscopic procedures could limit the comparison of the approach.

\section{Conclusion}

Standardized step-up approach, shows improved outcomes in mortality and requirement of surgical procedures in infected pancreatic necrosis. Based on our series of cases, the multidisciplinary approach and expertise of interventionist radiologists shows increased rates of success in percutaneous drainage (trans-gastric or trans abdominal), in the absence of interventionist endoscopy, no differences observed in clinical outcomes between trans-gastric or trans-abdominal approach. Further prospective studies are needed to prove our results.

\section{Declarations}

\section{Statements}

The authors have no relevant financial or non-financial interests to disclose.

The authors have no competing interests to declare that are relevant to the content of this article.

All authors certify that they have no affiliations with or involvement in any organization or entity with any financial interest or non-financial interest in the subject matter or materials discussed in this manuscript.

The authors have no financial or proprietary interests in any material discussed in this article.

\section{Author's contribution}

$\mathrm{CR}, \mathrm{DC}, \mathrm{FG}, \mathrm{MQ}$ : Conception of the idea, protocol structuration, data analysis, manuscript draft, critical revision of the manuscript.

DA, JG: Data recollection, data analysis, manuscript draft.

Funding: This paper does not receive any funding.

\section{Authors do not declare any conflict of interest}

\section{References}

1. Boxhoorn L, Voermans RP, Bouwense SA, Bruno MJ, Verdonk RC, Boermeester MA, van Santvoort HC, Besselink MG. Acute pancreatitis. Lancet. 2020 Sep 5;396(10252):726-734. doi: 10.1016/S01406736(20)31310-6. PMID: 32891214.

2. Riveros, R., Nieto, J. A., \& Vargas, F. (2008). Pancreatitis Aguda. Bogotá: Universidad del Rosario Editorial. Retrieved from https://repository.urosario.edu.co/bitstream/handle/10336/1019/Pancreatitis aguda.pdf 
3. Forsmark CE, Baillie J, Practice AGAIC, Economics C, Board AGAIG (2007) AGA Institute technical review on acute pancreatitis. Gastroenterology 132 (5):2022-2044. https://doi.

org/10.1053/j.gastro.2007.03.065

4. Colvin SD, Smith EN, Morgan DE, Porter KK. Acute pancreatitis: an update on the revised Atlanta classification. Abdom Radiol (NY). 2020 May;45(5):1222-1231. doi: 10.1007/s00261-019-02214-w. PMID: 31494708

5. NIETO, J. A. .; RODRÍGUEZ, S. J.. Manejo De La Pancreatitis Aguda: Guía De práctica clínica Basada En La Mejor información Disponible. Rev Colomb Cir 2019, 25, 76-96. Retrieved: http://www.scielo.org.co/scielo.php?script=sci_arttext\&pid=S2011-75822010000200003

6. Pérez F, Arauz Valdes E. Pancreatitis Aguda: Artículo de Revisión. Rev méd cien t. 2020; Volumen 33: página 67 -88. DOI: 10.37416/rmc.v33i1.570

7. Colvin SD, Smith EN, Morgan DE, Porter KK. Acute pancreatitis: an update on the revised Atlanta classification. Abdom Radiol (NY). 2020 May;45(5):1222-1231. doi: 10.1007/s00261-019-02214-w. PMID: 31494708)

8. Jinno N, Hori Y, Naitoh I, Miyabe K, Yoshida M, Natsume M, Kato A, Asano G, Sano H, Hayashi K. Predictive factors for the mortality of acute pancreatitis on admission. PLoS One. 2019 Aug 22;14(8):e0221468. doi: 10.1371/journal.pone.0221468. PMID: 31437218; PMCID: PMC6706052

9. Lankisch PG, Apte M, Banks PA. Acute pancreatitis. Lancet. 2015 Jul 4;386(9988):85-96. doi: 10.1016/S0140-6736(14)60649-8. Epub 2015 Jan 21. Erratum in: Lancet. 2015 Nov 21;386(10008):2058. PMID: 25616312.

10. Rodríguez, E. B. M. (2018). Caracterización de los pacientes con Pancreatitis Aguda que ingresaron al Hospital Universitario Nacional entre Abril de 2016 y Septiembre de 2017. Bogotá. Retrieved from https://repositorio.unal.edu.co/bitstream/handle/unal/62919/Caracterización de los pacientes con Pancreatitis Aguda que ingresan al HUN Final.pdf?sequence=1\&isAllowed=y

11. Paulino J, Ramos G, Veloso Gomes F. Together We Stand, Divided We Fall: A Multidisciplinary Approach in Complicated Acute Pancreatitis. J. Clin. Med [internet] 2019 [consultado 26 oct 2019 ]; 8 (1607). Disponible en: https://doi.org/10.3390/jcm8101607

12. Mancilla, C. A., \& Sanhueza, A. S. (2010). Clasificación de Balthazar-Ranson. Gastroenterol. Latinoam, 21(3), 415-417. Retrieved from https://gastrolat.org/DOI/PDF/10.0716/gastrolat2010n300012.pdf

13. Pérez Chaca, G. (2017). Rol del drenaje percutáneo en las colecciones pancreáticas postpancreatitis aguda. Mendoza, Argentina. Retrieved from http://revistaintervencionismo.com/wpcontent/uploads/INT_2016_048_Revision.pdf

14. an Santvoort HC, Bakker OJ, Bollen TL, Besselink MG,Ali UA, Schrijver AM, et al. A Conservative and Minimally Invasive Approach to Necrotizing Pancreatitis Improves Outcomes. Gastroenterology. 2011;141:1254-63 DOI:10.1053/j. gastro.2011.06.073

15. Bennett S, Lorenz JM. The Role of Imaging-Guided Percutaneous Procedures in the Multidisciplinary Approach to Treatment of Pancreatic Fluid Collections. Semin Intervent Radiol. 2012;29:314-8. DOI: 


\section{$10.1055 / \mathrm{s}-0032-1330066$}

16. Hollemans RA, Bollen TL, van Brunschot S, Bakker OJ, Ali UA, van Goor H, et al. Predicting Success of Catheter Drainage in Infected Necrotizing Pancreatitis. Ann Surg. 2016;263:787-92. DOI: 10.1097/SLA.0000000000001203

17. Fabbri C, Luigiano C, Maimone A, Polifemo AM, Taran- tino I, Cennamo V. Endoscopic ultrasoundguided drainage of pancreatic fluid collections. World J Gastrointest Endosc 2012; 4(11): 479-488 Available from: URL: http://www.wjg- net.com/1948-5190/full/v4/i11/479.htm DOI: http://dx.doi. org/10.4253/wjge.v4.i11.479

18. Varadarajulu S, Lopes TL, Wilcox CM, Drelichman ER, Kilgore ML, Christein JD. EUS versus surgical cyst-gastros- tomy for management of pancreatic pseudocysts. Gastrointest Endosc 2008; 68: 649655

19. Sion MK, Davis KA. Step-up approach for the management of pancreatic necrosis: a review of the literature. Trauma Surg Acute Care Open. 2019 May 19;4(1):e000308. doi: 10.1136/tsaco-2019000308. PMID: 31245622; PMCID: PMC6560663.

20. Besselink MG, van Santvoort HC, Nieuwenhuijs VB, Boermeester MA, Bollen TL, Buskens E, Dejong $\mathrm{CH}$, van Eijck CH, van Goor H, Hofker SS, Lameris JS, van Leeuwen MS, Ploeg RJ, van Ramshorst B, Schaapherder AF, Cuesta MA, Consten EC, Gouma DJ, van der Harst E, Hesselink EJ, Houdijk LP, Karsten TM, van Laarhoven CJ, Pierie JP, Rosman C, Bilgen EJ, Timmer R, van der Tweel I, de Wit RJ, Witteman BJ, Gooszen HG; Dutch Acute Pancreatitis Study Group. Minimally invasive 'step-up approach' versus maximal necrosectomy in patients with acute necrotising pancreatitis (PANTER trial): design and rationale of a randomised controlled multicenter trial [ISRCTN13975868]. BMC Surg. 2006 Apr 11;6:6. doi: 10.1186/1471-2482-6-6. PMID: 16606471; PMCID: PMC1508161.

21. Bakker OJ, van Santvoort HC, van Brunschot S, et al. Endoscopic Transgastric vs Surgical Necrosectomy for Infected Necrotizing Pancreatitis: A Randomized Trial. JAMA. 2012;307(10):10531061. doi:10.1001/jama.2012.276

22. Sharma, P., Sharma, S., Yadav, A., \& Rotem, E. (2019). CT Guided Percutaneous Drainage in Necrotizing Pancreatitis - Highly Successful in Appropriately Selected Patients - Single Center Experience. Journal of the Pancreas, 20.

23. Freeny PC, Hauptmann E, Althaus SJ, Traverso LW, Sinanan M. Percutaneous CT-guided catheter drainage of infected acute necrotizing pancreatitis: techniques and results. AJR Am J Roentgenol 1998; 170:969- 975. [PMID: 9530046]

24. Wroński M, Cebulski W, Karkocha D, Słodkowski M, Wysocki L, Jankowski M, Krasnodębski IW. Ultrasound-guided percutaneous drainage of infected pancreatic necrosis. Surg Endosc. 2013 Aug;27(8):2841-8. doi: 10.1007/s00464-013-2831-9. Epub 2013 Feb 13. PMID: 23404151; PMCID: PMC3710405.

25. Davies, R.P., Cox, M.R., Wilson, T.G. et al. Percutaneous cystogastrostomy with a new catheter for drainage of pancreatic pseudocysts and fluid collections. Cardiovasc Intervent Radio/ 19, 128-131 (1996). https://doi.org/10.1007/BF02563909 
26. Van Sonnenberg E, Wittich GR, Casola G, Branningan TC, Karnel F, Stabile BE, Varney RR, Christensen RR (1989) Percutaneous drainage of infected and reinfected pancreatic pseudocysts: Experience in 101 cases. Radiology 170:757-761

27. Fattar S (1990) Percutaneous drainage of panacreatic pseudocysts: Technique and problems. Australas Radiol 34:334-338

\section{Figures}

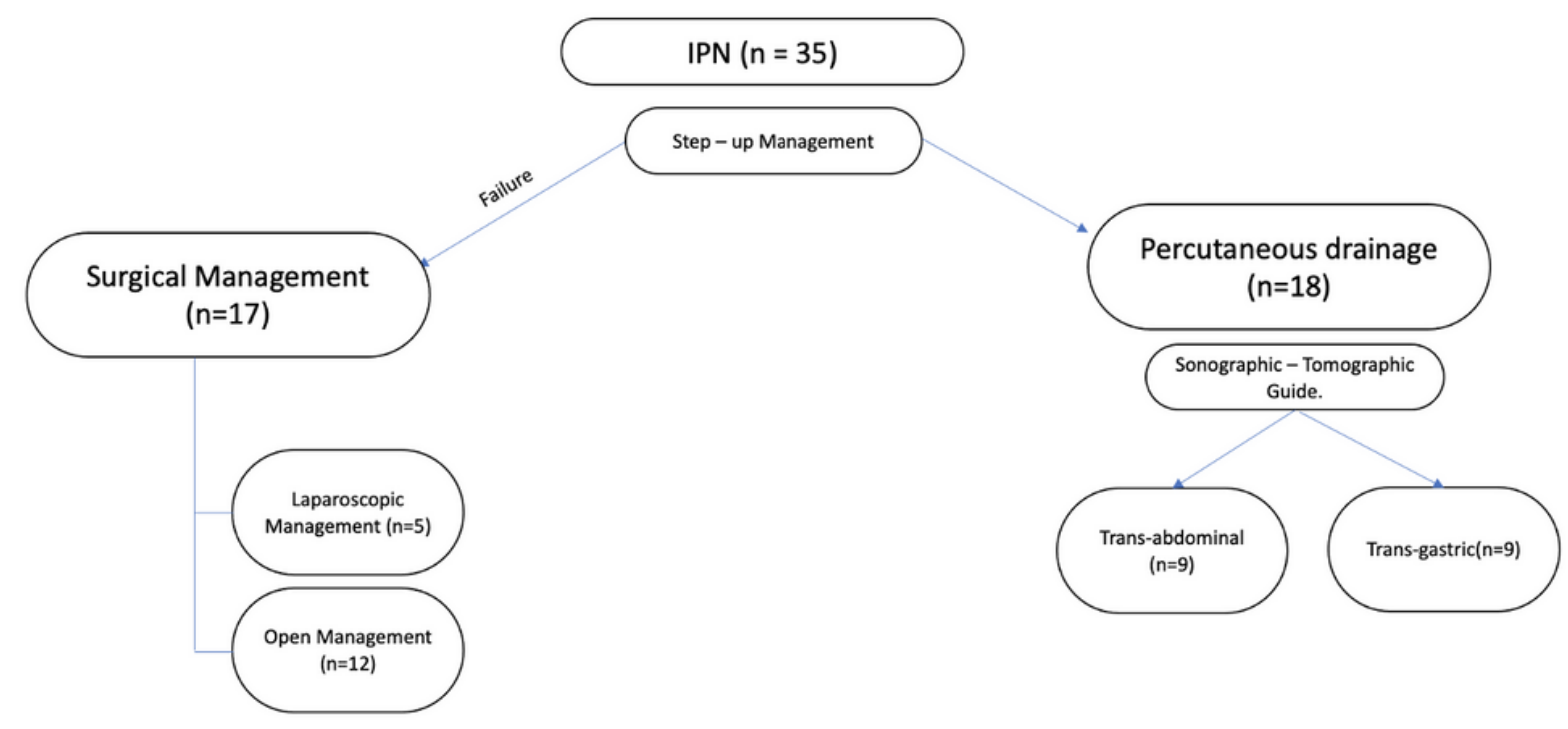

Figure 1. Flow - chart decision process

IPN: Infected pancreatic necrosis.

।

\section{Figure 1}

See image above for figure legend 